\title{
A Review on Success and Failures of Conservation Agriculture Practices in Ethiopia
}

\author{
Tesfaw Melkamu Adugna, Dessie Almaw Cherie* \\ Ethiopian Institute of Agricultural Research (EIAR), Assosa Agricultural Research Center, Assosa, Ethiopia \\ Email address: \\ dalmaw121@gmail.com (D. A. Cherie) \\ ${ }^{*}$ Corresponding author \\ To cite this article: \\ Tesfaw Melkamu Adugna, Dessie Almaw Cherie. A Review on Success and Failures of Conservation Agriculture Practices in Ethiopia. \\ International Journal of Environmental Chemistry. Vol. 5, No. 1, 2021, pp. 7-11. doi: 10.11648/j.ijec.20210501.12
}

Received: February 4, 2021; Accepted: April 27, 2021; Published: May 14, 2021

\begin{abstract}
Agribusiness possesses a key position for the Ethiopian economy, which contributes inside a single year $85 \%$ of business of the country's populace, $95 \%$ of arrive beneath development and contributes more than $96 \%$ add up to rural yields. Be that as it may, the conventional arrive utilize framework harms this division and welcome over the top soil disintegration by wind and water (runoff) and results the misfortune of soil efficiency. In this respect, conservation agriculture can be seen as a potential alternative for Ethiopia which depend primarily and farming appear prime segment that seem offer assistance in keeping up and moving forward trim abdicate, achieving more flexible cultivating framework with decreased dangers and risks, whereas ensuring and invigorating the biological work of the soil. Most past ponders advocate appropriation of conservation agriculture as a degree for issues brought in ordinary cultivating operation and broad cultivate inputs application center on commerce as regular that pointed as it were maximizing generation, but this innovation have been limitedly received in a few zones. The catastrophe is little agriculturists may come up short to completely acknowledge recommended agrarian innovation bundles, such as conservation agriculture center hones due to numerous components, counting asset and data limitations. In this manner, the point of this article centered on the success and disappointment of conservation agriculture hones in Ethiopia.
\end{abstract}

Keywords: Conservation Agriculture, Ethiopia, Failure, Success

\section{Introduction}

Current and future global environmental change, in combination with population growth and increase in consumption per capita, poses a great threat to global food security. Estimation states that if the current trends in diet and food waste continue, food manufacture will increase by $60 \%$ by 2050 from $2005 / 2007$ to supply the well above 9 billion people that is expected [1]. The majority of countries, whose population growth is estimated to be highest, are precisely those showing the highest levels of food insecurity and malnutrition. Ethiopia is one the threatened country of these climate change impact on food security. Even though the country is endowed with bulk of natural resources, in proper land uses because of population growth and lack of consciousness of farmers, drought was a challenge for the agriculture. Agribusiness possesses a key position for the Ethiopian economy, which contributes inside a single year $85 \%$ of business of the country's populace, $95 \%$ of arrive beneath development and contributes more than $96 \%$ add up to rural yields. Farming is the back bone of Ethiopian national economy. Around $50 \%$ of net housing item and $90 \%$ of its exterior trade pay is accounted by agriculture [2]. Be that as it may, the customary arrive utilize hone harms this segment and welcome over the top soil disintegration by wind and water, and soils are exhausted of supplements and incapable to normally support crops $[3,4]$.

Preservation culturing is the collective umbrella term commonly given to no-tillage, direct-drilling, minimumtillage and/or ridge-tillage, to represent that the particular hone features a preservation objective of a few nature. As a rule, the maintenance of $30 \%$ surface cover by buildups characterizes the lower restrain of classification for conservation-tillage, but other preservation goals for the hone incorporate preservation of time, fuel, worms, soil water, soil structure and supplements. In this way buildup levels alone don't satisfactorily depict all preservation culturing hones [5, 6]. 
Compared to intensive tillage based agriculture, conservation agriculture (CA) has the promising to decrease soil loss, enhance levels of soil organic matter, increase plant available soil water, and save costs due to smaller amount or no tillage actions [7].

Since Ethiopia has great climatic diversity, from dry to wet, and also many different altitudes, from lowlands to highlands, the same conservation technologies cannot be applied everywhere. As a result, it is necessary to identify the characteristics of an area where soil and water conservation is to be implemented. Cultivated farm land requires conservation actions different from those required on grassland.

Activities, in the presence of the yield maximizing farm inputs and information constraints farmers faced low productivity in developing countries, sustainable farming that relies on renewable local farm resources presents attractive options for enhancing agricultural productivity [8].

In this respect, preservation agribusiness (CA) may be seen as a potential choice for Ethiopia which depend basically and agribusiness appear prime division that seem offer assistance in keeping up and moving forward trim surrender, accomplishing more versatile cultivating framework with diminished dangers and risks, whereas ensuring and invigorating the organic work of the soil [9]. The objective was to survey on the victory and disappointment of hones of preservation horticulture in Ethiopia.

\section{Review of Literature}

\subsection{Experience of Conservation Agriculture in Ethiopia}

The practice with conservation agriculture in Ethiopia is limited. However, some projects have been implemented in the country, conservation agriculture practices is not adaptable through the farmers [10], which provides some of the most comprehensive and updated information on the subject following the serious problems of soil nutrient depletion and workshop held on Ghana Accra 1996 conservation agriculture practices, including minimum or no tillage have long been experienced by agriculturists, CA and its related bundle of best hones was presented in Ethiopia, as agriculture-environment administration [11] and Mokabu endeavor as it were in 1998 on 77 maize plots Matsumoto et al., (2004) [12]. In arrange to capture the misfortune of the topsoil, construct natural matter, move forward soil structure, and upgrade water and supplement capacity, the conventional framework must be supplanted by preservation (least culturing) approach SG $(2000,2004)$ [13].

\subsection{Success of Practices of Conservation Agriculture in Ethiopia}

In Ethiopia, soil conservation practices such as reduced tillage; have all over the history erratically been undertaken by farmers in different places as a conventional method. However, the active promotion of conservation agriculture technology is quite new and started in 1998 by something called the Sasakawa Global 2000 initiative. During the initial period of conservation agriculture from 1999 to 2003, trials indicated that conservation agriculture plots on maize, teff and sorghum had higher yields compared to conventional tillage [14]. They also indicated lower production costs. Despite conservation agriculture having been introduced in Ethiopia over 18 years ago, adoption of the practice remains low and has not progressed as fast is it could have. Since its introduction, CA has been promoted mainly by NGOs and the private sector with support from agricultural offices at all levels. The Ethiopian government has put in place policies, strategies and manuals that are designed to support CA practices and other forms of sustainable agriculture methods aiming at restoring ecosystems and managing natural resources.

The Agricultural Transformation Agency's (ATA) [15] target for 2014 was to have 50,000 farmers practicing CA, and as a result of the promotional work that has been done, $\mathrm{CA}$ has been experienced by a number of smallholder agriculturists in numerous parts of the nation. It has been indicated that the practice has been most successful in the areas where CA have been adequately established, for example in some parts of Oromia, Amhara and Tigray regions of the country. The demonstrated in Tigray and Amhara region showed that almost $13.2 \%$ and $34.5 \%$ of the total sample test plots in Tigray, and $14.6 \%$ and $30.3 \%$ in Amhara locale utilized decreased culturing [16].

Agreeing to (Tsegaye, 2016) [17] a consider drained the central Ethiopia appeared that graphic insights appear that current extent of CA adopters out of the entire test is almost $57 \%$. The extent of adopters is higher in Ada'aChukala (72\%) compared to BakkoTibe (48\%). Non adopters are families that utilized none of the CA components. Among the adopters, $10 \%$ have utilized as it were one component, $75 \%$ have embraced two components, and $15 \%$ have received all three components. Nine of the eleven agriculturists who embraced as it were a component are applying herbicides, and the other two are utilizing least culturing alone. Almost $87 \%$ of the adopters detailed they did plowing in line with CA's reasoning, i.e., least soil unsettling influence. Plowing recurrence is higher in Ada'a Chukala for both-adopters (1.83/season) and non-adopters (3.26/season) of CA compared to adopters (1.00/ season) and non-adopters (1.96/season) in Bakko Tibe.

However, in general, CA practice rates in Ethiopia are not well enough documented. In terms of practicing different $\mathrm{CA}$ components [18] from two districts in Ethiopia found that those farmers who had practiced all three components of CA had higher yields than those didn't practiced. Examined teff (Eragrostis abyssinica) ranches beneath conventional culturing hone, conventional wrinkle based water preservation, and changeless beds (PB) in northern Ethiopia and detailed that surrender, biomass, and plant stature of teff were essentially higher in conventional culturing hone than in Changeless Beds [19]. Conducted a ponder on forever kept rain-fed exploratory Vertisol plots to compare conservation 
agriculture that coordinates in situ soil and water preservation culturing hones and a ordinary framework [20].

\subsection{Failure of Practices of Conservation Agriculture in Ethiopia}

Even if CA practices supported by different studies but in the most parts of Ethiopia farmers would vacillate to use this practice because of problems and misunderstanding in relation with labor, income, land holding and tenure rights, Tropical Livestock Unit (TLU), type of technology and knowledge. Farmers by themselves are not committing devil but because of information gap. They have may hinder adoption of conservation agriculture at required speed and time and made it be fragile instead of universal remedy.

The acceptance of conservation agriculture technology in Ethiopia was inhibited by various factors. FAO's study [21] found that the guidelines from the authorities are not on a adequately detailed level, and manuals and action plans and are not sufficiently mainstreamed into obtainable programs and projects. In addition, there are challenges of weak integration into existing extension services, prevalence of open grazing, shortage of livestock feed, and lack of knowledge on appropriate cropping systems, crop rotations and intercropping combinations. In many areas of Ethiopia, lack of land is also a big problem. Land is traditionally split up into smaller entities among the siblings upon inheritance, which lead to a decline in farm size. Conservation agricultural practices in Ethiopia has a problem association between higher population density and smaller farm sizes [22].

In addition, they point to a resulting increase in the use of fertilizer per hectare. However, increased input use is not corresponding with increase in yields, by that resulting in income decline on the farm level. Moreover, even though it has been found that crop yields from CA fields increase, application of reduced or no tillage and maintaining permanent soil cover was by GIZ found to be uneasy for farmers [23] because of two reasons. The first challenge was weed infestation. Farmers used to plough their fields numerous times to get rid of weeds, thus depending less on herbicides. When they stopped tilling, more weeds would grow, and to cope with the change, farmers had to face the problem of both accessing and affording herbicides.

The second challenge was that farmers did not want to leave crop residues in the field. But, FAO [21] argues that the success of CA in Ethiopia is highly dependent on crop residue management. In many parts of the country, crop residues have traditionally been used for multiple purposes that conflicts with their use in CA, the most widespread being livestock-related feed. Studies indicate that in the highlands of Ethiopia, crop residue covers $40-50 \%$ of the feed for smallholder farmers [24]. This implies that widespread CA adoption will entail large-scale changes in the traditional mixed farming-livestock systems. Since communities often practice open grazing systems, it is in most cases not an individual matter of whether or not a farmer can or wants to adopt CA.
GIZ argues that farmers need to have access to alternative sources of animal feed, and access to herbicides (at least in the first two years), in order to overcome important adoption barriers in Ethiopia (2015). Also, GIZ points to the need for farmers to be organized into groups in order to apply the practices and share experiences. Based on findings from research on soil conservation techniques implemented in the SLM program, [25] claim that due to the standardized input package approach and inflexible input distribution systems in Ethiopia, farmers have had little opportunity to experiment, learn, and adapt technologies to their own needs. Systematic knowledge-sharing and more farm-level experimentation seems to be needed.

Therefore, the full positive effects of CA are only likely to be revealed several years after adoption. Poor farmers' lack of safety nets leads to a risk-aversion and short-termism that constitute a significant barrier. Even though smallholders may believe that crop yields will increase with CA, the future benefits often do not compensate for their immediate needs to supply for their family [26]. Because of this, the short term need of domestic consumption takes priority. The study showed that typically, about $50 \%$ of households reported credit demand and not found it. In Ethiopia, Kenya and Malawi credit constrained households were 56\%, 45\% and $49 \%$ to demonstrate and adopt CA practice [27].

Interests sufficient, an examination [28] appears that CA to begin with and preeminent has been embraced beneath the premises of being energy-saving (time and/or control), erosion-controlling, and water-use proficient. The argument of increased yields has more rarely been used as a reason for adopting. This may indicate that the promise of higher yields in itself is not the argument that ways farmers into adoption. However, it also means that they must find the other arguments all the more important if they are going to be willing to implement Conservation Agriculture.

\section{Conclusion}

Ethiopia could be a nation where characteristic assets debasement is exceptionally genuine and a declining issue for vocations, advancing soil preservation strategies such as CA is an vital intercession toward accomplishing nourishment security through maintainable cultivating. In spite of the fact that the appropriation level is very empowering, generally few ranchers are receiving all the three components of CA. In any case, basic comparisons based on arrive and labor productivities don't legitimize selection of all three components.

Preservation horticulture could be a demonstrate of economical agribusiness because it leads to productive nourishment generation whereas securing and indeed reestablishing common assets. Preservation farming benefits ranchers since it diminishes generation costs and increments yields, but it too has positive impacts on the total society: improvement of nourishment security much appreciated to a stronger soil ripeness, advancement of water quality, decrease of disintegration and relief of climate alter by expanding 
carbon sequestration, etc. The fundamental guideline of preservation horticulture is to play down soil-disturbance in arrange to stabilize soil structure, increment richness and adjust the environment. Indeed in spite of the fact that it isn't adequate $\mathrm{CA}$ was practiced in a few parts of the nation since of advancement of non-governmental organizations. Be that as it may, need of commonsense commitment, moo mindfulness of ranchers to $\mathrm{CA}$ innovation, little arrive holding, free animals brushing and so numerous limitations were lead to disappointment of CA hone in Ethiopia.

\section{References}

[1] McKenzie, F. C.; Williams, J. (2015). Sustainable food production: constraints, challenges and choices by 2050 . Food secure, 7, 221-223.

[2] EEA (Ethiopian Economic Association) / EEPRI (Ethiopian Economic Policy Research Institute). 2006. Evaluation of the Ethiopian Agricultural Extension with Particular Emphasis on the Participatory Demonstration and Training Extension System (PADETES). Addis Ababa, Ethiopia: EEA/EEPRI.

[3] Nunes, J. S.; Araujo, A. S. F.; Nunes, L. A. P. L.; Lima, L. M.; Carneiro, R. F. V.; Tsai, S. M.; Salviano, A. A. C. Land degradation on soil microbial biomass and activity in Northeast Brazil. Pedosphere 2012, 22, 88-95.

[4] Habig, J.; Hassen, A. I.; Swart, A. Application of microbiology in conservation agriculture. In.

[5] Baker CJ, Saxton KE, \& Ritchie WR. 2002. No-tillage seeding: science and practice. $2^{\text {nd }}$ Edition. $\mathrm{CAB}$ International. Oxford, UK.

[6] Kassam, A., Friedrich, T., Shaxson, F., \& Pretty, J. (2009). The spread of conservation agriculture: justification, sustainability and uptake. International Journal of Agricultural Sustainability, 7 (4), 292-320.

[7] Conservation Agriculture; Farooq, M., Kadambot, H. M., Eds.; Springer International Publishing.

[8] Bedada, W., Karltun, E., Lemenih, M. \& Tolera, M. 2014. long term addition of compost and NP fertilizer increases crop yield and improves soil quality in experiments on smallholder farms. Agriculture, Ecosystems and Environment, 195, 193-201.

[9] Teklu Erkossa., 2011. Tillage effects on physical qualities of vertisol in the central highlands of Ethiopia. African Journal of Environmental Science and Technology 5: 008-1016.

[10] Sil Lanckriet, Tesfay Araya, Ben Derudder, Wim Cornelis, Hans Bauer, Bram Govaerts, Jozef Deckers, Mitiku Haile, Jozef Naudts \& Jan Nyssen (2014) Toward Practical Implementation of Conservation Agriculture: A Case Study in the May Zeg-zeg Catchment (Ethiopia), Agroecology and Sustainable Food Systems, 38: 8, 913-935.

[11] Stewart, N \& Thiebault, M. 2015. Soil Degradation and Sustainable Land Management in the Rainfed Agricultural Areas of Ethiopia: An Assessment of the Economic Implications. The Economics of Land Degradation, Bonn.

[12] MOARD (ministry of Agriculture and rural development) "Adapting to Climate Change through participatory promotion and Demonstration of Conservation Agriculture (CA) in East
Gojjam Zone, Amhara National Regional State" (1215186-03 Ethiopia-MoA project).

[13] Alexandratos, N. and Bruinsma. J (2012). World agriculture towards 2030/2050: the 2012 revision. ESA Working paper No. 12-03. FAO, Rome.

[14] Sasakawa-Global (2000, 2004). Proceedings of the Workshop on Conservation Tillage. Melkassa Agricultural Research Center, East Shewa, Ethiopia, April 6, 2004.

[15] The Agricultural Transformation Agency's (ATA) target conservation agriculture for (2014) annual report

[16] Kassie Menale., Zikhali, Manjur and Edwards S. (2009). Adoption of organic farming techniques: Evidence from a Semi-Arid Region of Ethiopia. Discussion paper series. January 2009. EDIF-09.

[17] Wondwossen, T., Roberto, L., Germano, G., T. Kassie., (2016). Adoption and farm-level impact of conservation agriculture in Central Ethiopia. Environ Dev Sustain DOI 10.1007/s10668-016-9869-5.

[18] Tigist Oicha, Wim M. Cornelis, Hubert Verplancke, Jan Nyssen, Bram Govaerts, Mintesinot Behailu, Mitiku Haile, Jozef Deckers (2010). Short-term effects of conservation tillage on soil (Vertisol) and crop (teff, Eragrostis tef) attributes in the northern Ethiopian highlands. 2010, 19th World Congress of Soil Science, Soil Solutions for a Changing World $1-6$ August 2010, Brisbane, Australia. Published on DVD.

[19] Araya T, Cornelis WM, Nyssen J, Govaerts B, Gebregziabher T, Oicha T, Getnet F, Raes D, Haile M, Sayre KD, Deckers J (2010). Impact of conservation agriculture on runoff, soil loss and crop yield on a Vertisol in the northern Ethiopian highlands. In 'Proceedings of 19th World Congress of Soil Science, Soil Solutions for a Changing World, Brisbane'.

[20] Tesfay Araya, Jan Nyssen, BramGovaerts, Jozef Deckers, and Wim M. Cornelis. (2015) Impacts of conservation agriculturebased farming systems on optimizing seasonal rainfall partitioning and productivity on vertisols in the Ethiopian dry lands, Soil and Tillage Research 148, 1-13.

[21] FAO. (2016). Ethiopia Climate-Smart Agriculture Scoping Study. By Jirata, M., Grey, S. \&Kilawe, E. FAO, Addis Ababa.

[22] A. L. Josephson, J. R.- Gilbert and Raymond J. G. M. Florax. How does population density influence agricultural intensification and productivity? Evidence from Ethiopia / Food Policy 48 (2014) 142-152.

[23] GIZ. (2015). GIZ Ethiopia: Lessons and Experiences in Sustainable Land Management. Deutsche Gesellschaftfür Internationale Zusammenarbeit (GIZ), Addis Ababa.

[24] Corbeels, M., de Graaff, J., Ndah, T. H., Penot, E., Baudron, F., Naudin, K., Andrieu, N., Chirat, G., Schuler, J., Nyagumbo, I., Rusinamhodzi, L., Traore, K., Mzoba, H. D. and Adolwa, I. S. (2013). Understanding the impact and adoption of conservation agriculture in Africa: A multi-scale analysis. Agriculture, Ecosystems and Environment, 187, 155-170.

[25] Baudron, F., Delmotte, S., Corbeels, M., Herrera, J. and Tittonell, P. (2015a). Multi-scale trade-off analysis of cereal residue use for livestock feeding vs. soil mulching in the MidZambezi Valley, Zimbabwe. Agricultural Systems, 134, 97106. 
[26] CSA.(2008). Summary and Statistical Report of the 2007 Population and Housing Census. Population Size by Age and Sex. Central Statistical Authority, Addis Ababa.

[27] Paswel M., Menale K., Moti Jaleta, Dil R., and Olaf E. (2015) Adoption of Conservation Agriculture Under Alternative Agricultural Policy and Market Access Indicators: Evidence From Eastern and Southern Africa. International Conference of Agricultural Economists (ICAE). Agriculture in an Interconnected World.

[28] Kassam, A. H., Friedrich, T. and Derpsch, R. (2010) Conservation Agriculture in the 21st Century: A Paradigm of Sustainable Agriculture. Invited paper at the European Congress on Conservation Agriculture, October 2010, Madrid, Spain. 